\title{
URGENSI PENGEMBANGAN KARAKTER MANDIRI DALAM MENGEMBANGKAN KECERDASAN MORAL MELALUI PEMBELAJARAN DARING
}

\author{
Muhammad Kholil \\ Universitas Nurul Jadid \\ 1madkholil@gmail.com \\ Muhammad Mushfi El Iq Bali \\ Universitas Nurul Jadid \\ mushfieliqbali8@gmail.com \\ Siti Fatimah \\ Universitas Nurul Jadid \\ sitifatimahifa08@gmail.com
}

\begin{abstract}
Sophisticated information technology can have a great influence on the shape of human life, especially through information and the use of the internet which is free and without limits. The process of forming character education in the school environment really helps students in matters of responsibility through ethical development and the process of training character well through universal values. This type of research is using a descriptive qualitative research approach. This study collects data in the form of data in the form of sentences or describes from the subject carried out by interview. The subjects consisted of Islamic


Religious Education teachers at MAN 2 Probolinggo. The data from this study are the results of interviews with subjects who describe the urgency of developing independent character in developing moral intelligence through online learning. The teacher's efforts in the process of teaching and learning activities always review those related to values, morals and attitudes with simple events, reminding them to have tolerance, fairness, empathy, and increasing respect for teachers or for older people and events that concerned with morals.

Kata kunci: Independent Character, Moral Intelligence, Online Learning

\section{Pendahuluan}

Keberhasilan dari hasil proses pendidikan tidak lepas dengan proses pembentukan perencanaannya, pelaksanaan pendidikan, dan kebijakan penunjang yang dilakukan secara berkelanjutan. Karena pendidikan itu hal utama yang harus yang dibangun maka disetiap negara sudah menjadi tujuan utama. Dengan adanya perkembangan globalisasi yang sangat semakin maju pada masa saat ini yang dapat mempengaruhi kekuatan untuk mengikis jati diri bangsa. Sophisticated information technology can significantly influence buman life, primarily through free and unlimited information and the use of the internet. ${ }^{1}$ Selain itu, merambatnya budaya luar yang kurang sesuai untuk karakter budaya penduduk Indonesia dengan nilai-nilai kehidupan yang bebas dapat merusak suatu moral manusia.

Adanya tujuan pendidikan adalah agar mencetak generasi yang dalam keadaan utuh dengan memiliki kecerdasan yang tinggi dan akhlak yang baik dan juga melaksanakan keterampilan atau skill dikehidupan masyarakat sekitar. Sebagai dari proses pendidikan agar mendapatkan hasil pembelajaran yang outputnya adalah suatu keseimbangan dengan tercapainya keterampilan afektif atau sikap/akhlak dan psikomotor ialah peran seorang guru dalam pelaksanaan pembelajaran. Peran seorang guru sangatlah penting, guru wajib mampu menjadi fasilitator dan menjelaskan kelemahan model-model dan segala keunggulan pembelajaran yang akan diterapkan sehingga benar-benar menjadikan suatu pembelajaran yang baru dari hasil pengaruh terhadap proses pembelajaran. Tipikal guru dalam mengajar pada dasarnya suatu usaha untuk melakukan sesuatu kondisi yang baru atau lingkungan yang sangat mendukung dan sesuatu

\footnotetext{
1 Dakir et al., "Design Seamless Learning Environment in Higher Education with Mobile Device," in WEAST 2020 (IOP Publishing, 2021), 1-6, https://doi.org/10.1088/1742-6596/1899/1/012175.
} 
yang dapat terjadi secara berlangsungnya proses belajar. ${ }^{2}$ Belajar yaitu suatu tindakan tingkah laku atau perbuatan dengan membaca seorang siswa tahu tentang proses kegiatan belajar seperti mengamati, meniru dengan sesuai contohnya, dan dengan cara mendengarkan dapat mengetahui proses pengamatannya. Belajar juga akan menghasilkan yang lebih baik jika pokok pembelajarannya itu dengan cara melakukan atau pernah mengalami.

Pada masa Covid-19 seperti ini, pemerintah menghimbau suatu kebijakan tentang adanya pelaksanaan pembelajaran daring. Dijelaskan dalam kamus besar besar Indonesia yang diartikan terhubung dengan jaringan internet melalui jejaring computer, Leptop, Hp dan sebagainya. ${ }^{3}$ Online learning is carried out with the excuse of taking the proper steps to prevent breaking the chain of the spread of the Corona Virus. This method prevents students from missing lessons during the pandemic, as prepared in the curriculum for one academic year. ${ }^{4}$ Walaupun pemerintah sudah menghimbau suasana yang baru "New Normal' yaitu dengan merevitalisasi kembali perekonomian masyarakat yang sudah kurang lebih empat bulan tidak bergerak akibat dampaknya Covid-19. Akan tetapi lingkungan pendidikan seperti pembelajaran di sekolah seluruhnya belum sepenuhmya dibuka oleh pemerintah.

Untuk memutus mata rantai penyebaran Covid-19, dari beberapa oraganisasi kesehatan menyampaikan untuk mengakhiri agenda yang bisa menimbulkan kerumunan. Sehingga pada awalnya pembelajaran dilakukan secara tatap muka di sekolah tetapi diubah dengan secara pembelajaran daring agar terhindarnya kontak secara langsung antara siswa dan guru maupun siswa dengan siswa yang lain. Upaya tersebut untuk terhindar dari penyakit Covid-19 dan seluruh warga negara Indonesia harus tetap mengikuti protocol seperti memakai masker, mencuci tangan, dan jaga jarak. ${ }^{5}$ Hal sepert ini dikarenakan anak sekolah diliburkan cenderung masih labil dan sangat senang berkumpul dengan teman sebayanya sehingga dapat memungkinkan terjadinya penyebaran

\footnotetext{
${ }^{2}$ Fathor Rozi, "Variations in Learning Methods; Upaya Dalam Mencetak Pakar Fiqh Melalui Pengembangan Pembelajaran Kitab Kuning Di Ma'had Aly," Tafaqqub: Jurnal Penelitian Dan Kajian Keislaman 9, no. 1 (2021): 81-98.

3 I Wayan Eka Santika, "Pendidikan Karakter Pada Pembelajaran Daring," Indonesian Values and Character Education Journal 3, no. 1 (2020): 8-19.

${ }^{4}$ Muhammad Mushfi El Iq Bali and Musrifah, "The Problems of Application of Online Learning in the Affective and Psychomotor Domains During the Covid-19 Pandemic," Jurnal Pendidikan Agama Islam 17, no. 2 (2020): 137-54, https://doi.org/https://doi.org/10.14421/jpai.2020.172-03.

5 Abdul Hamid Wahid, Muhammad Mushfi El Iq Bali, and Sofiatul Maimuna, "Problematika Pembelajaran Fiqih Terhadap Minat Belajar Siswa Dalam Pembelajaran Jarak Jauh,” Edureligia: Jurnal Pendidikan Agama Islam 05, no. 01 (2021): 1-17.
} 
virus tersebut. Oleh karena itu, pelaksanaan pembelajaran saat ini bersifat pembelajaran jarak jauh secara online atau daring. Situasi dan kondisi tersebut menjadi suatu tantangan tersendiri bagi seorang guru dalam rangka pencapaian hasil belajar terutama dalam usaha pengembangan pendidikan karakter mandiri dan kecerdasan moral anak.

Character education is a process of forming a school environment that helps students in matters of responsibility through ethical development and training character well through universal values. ${ }^{6}$ Adanya pendidikan karakter yang membentuk nilai pendidikan, pendidikan moral, pendidikan watak mempunyai tujuan agar luasnya pengetahuan dan kecakapan pada peserta didik dalam menentukan hal yang baik dan yang buruk, menjaga apa yang telah dimiliki yaitu sifat yang baik dan mempraktikkan sifat baik itu dalam kehidpan sehari-hari di sekolah maupun di luar seolah dengan cara sepenuh hati dan tulus. Untuk membiasakan pendidikan karakter, seseorang harus mengutamakan communities of character yaitu ada sekolah, keluarga, media institusi keagamaan, pemerintah dan sebagian pihak yang dapat mempunyai pengaruh nilai kepada peserta didik. Seluruh komunitas dari karakter seharusnya memberi contoh suatu hal yang dapat ditiru atau saling menguatkan antara para peserta didik, agar dapat diserap oleh siswa bagaimana cara bersikap yang baik terhadap orang tua, guru, teman dan lingkungan.

Ada tiga pokok tentang menjadi penyebab inkonsistensi para peserta didik dalam mempelajari tentang materi pelajaran. Pertama, untuk meningkatkan suatu motivasi siswa seorang guru harus mengubah teknik pembelajaran yang efisien. Kedua, keberadaan guru adalah sebagai kebutuhan siswa, akan tetapi menggurui siswa atau kepribadian belajar. Ketiga, proses selama pembelajaran yang menggunakan alat yang kurang mempunyai daya tarik dan kurang berpartisipatif antar siswa. Jadi, seorang guru melibatkan semua siswa di masa sekolah online saat ini agar pengetahuan siswa tetap aktif dan berkembang dengan menggunakan cara pembelajaran yang memiliki daya tarik, kemudian pembelajaran online dapat membiasakan seorang siswa agar belajar mandiri. ${ }^{8}$ Dengan melakukan pembelajaran di luar lingkungan sekolah dengan

\footnotetext{
${ }^{6}$ Muhammad Mushfi El Iq Bali and Devi Ruzifah, "Mitigation of Student Deviant Behaviour through Al-Ghazali's Perspective Spiritual Values in the Disruptive Era," Jurnal Pendidikan Progresif 11, no. 1 (2021): 63-76, https://doi.org/10.23960/jpp.v11.i1.20210.

7 Muhammad Mushfi El Iq Bali and Lailatul Rohmah, "Implementasi Pendekatan Eklektik Berbasis Sharing Zone," Murobbi: Jurnal Ilmu Pendidikan 6, no. 2 (2018): 152-67, http://jurnal.iaibafa.ac.id/index.php/murobbi/article/view/143.

8 Zamroni et al., "Leader Member Exchange Dalam Membangun Komunikasi Efektif Di Pondok Pesantren,” El-Bubuth: Borneo Journal of Islamic Studies 3, no. 1 (2020): 77-89.
} 
menggunakan pembelajaran daring yang sifatnya jarak jauh, tugas dan tanggung jawab ekstra serta tantangan bagi seorang guru agar bisa menciptakan suasana lingkungan pembelajaran yang baru dalam mencapai perkembangan etika, karakter peserta didik, dan tanggung jawab.

Kecerdasan moral bukan hanya tentang prestasi yang harus diutamakan dalam berhubungan dengan orang lain. Ada beberapa masalah tentang menyimpangnya kualitas moral pada anak. Perkembangan moral pada anak tidak akan berkembang sendirinya, tapi dengan diajarkannya seorang anak akan tahu seperti apa itu kecerdasan moral. The earlier moral intelligence is tanght, the higher the child's knowledge of achieving a solid character, namely growing to think, believe, and act morally. Menimbang suatu perkembangan, seorang siswa harus mempelajari materi-materi yang akan dipelajari. Kelompok tersebut dapat mengharapkan proses yang baik dan sesuai apa yang diharap dengan terus dididik, didorong, dikontrol yang baik. Disini juga adanya peran orang tua tetap memberi dorongan, support kepada anak selama pembelajaran daring, karena faktor pembelajaran daring membuat anakanak bermalas-malasan untuk belajar dan orang tua tetap sigap kepada anak agar tetap belajar.

Kecerdasan moral merupakan kecakapan dasar seseorang bagaimana melakukan tindakan sesuai dengan etika yang baik dan berlaku kepada orang lain. Selanjutnya, kecakapan seseorang dalam membedakan buruk dan tidak buruknya perbuatan, sehingga mengetahui nilai-nilai karakter yang baik dalam dirinya. Kecerdasan moral mampu membuat manusia bisa mengetahui dan memahami bagaimana cara mengendalikan dirinya sendiri dan orang lain. Selain itu, kecerdasan moral mampu dapat menyelesaikan suatu permasalahan dalam berbagai aspek kehidupan manusia, dengan suatu tindakan dan sikap yang baik dalam berhubungan dengan orang lain. ${ }^{10}$ Perlunya siswa dididik sejak dini sebagai penerus bangsa, agar dikemudian hari telah terbiasa dengan melakukan hal yang baik sesuai tujuh kebajikan yang dikembangkan dalam kecerdasan moral.

Kecerdasan moral yang dikembangkan melalui pembelajaran online (daring) meliputi upaya seorang guru mempunyai tanggung jawab

\footnotetext{
9 Muhammad Mushfi El Iq Bali et al., "Innovative Learning Media Based on ELearning in the New Normal Era," in 11th Annual International Conference on Industrial Engineering and Operations Management Singapore, 2021, 1-7.

${ }^{10}$ Muhammad Mushfi El Iq Bali, "Penerapan Model Pembelajaran Two Stay Two Stray Dalam Meningkatkan Keaktifan Belajar Matematika," Murobbi: Jurnal Imu Pendidikan 4, no. 1 (2020): 29-42.
} 
bagaimana caranya menjelaskan kepada peserta didik untuk membedakan hal yang baik dan buruk. Dengan hal ini, belum tentu apa yang dilakukan peserta didik baik meskipun itu sudah benar, padahal apa yang dilakukan oleh peserta didik itu berhadapan dengan moral yang berlaku di lingkungan masyarakat. Hal ini guru memiliki peran yang sangat penting tentang bagaimana membangun segi yang berkenan peserta didik disamping ada juga peran orang tua. As an example of a student, the teacher does not only act as an educator and teacher. ${ }^{11}$

Ada beberapa masalah tentang kecerdasan moral yang ditandai dengan turunnya nilai akhlak dan moral sehingga menjadi salah satu yang menimbulkan masalah di dunia pendidikan dan masyarakat diantaranya adalah meningkatnya tawuran, seks bebas, kekerasan dikalangan remaja atau pelajar, semakin pudarnya pedoman moral baik dan buruknya, penggunaan dan kata yang kurang baik dan rendahnya rasa hormat kepada orang tua dan guru, dan rendahnya rasa tanggung jawab peserta didik.

\section{Karakter Mandiri}

Karakter berarti watak atau kepribadian seseorang. Karakter sebagai penilaian mengenai kepribadian seseorang yang bersangkutan dengan kelengkapan yang dapat diterima atau tidak diterima oleh masyarakat. ${ }^{12}$ Karakter mencakup keseluruhan kemampuan dan pendapat yang telah dikuasai secara mantap atau tidak goyah yang didefinisikan seseorang individu tentang mencakup keseluruhan adab perilaku yang berhubungan dengan psikis yang menjadikan khas dalam cara berfikir dan bertindak.

Character formation is related to attitudes, motivation, behavior, and skills. Derived character is a way to focus or mark the application of good values in the form of behavior or action. ${ }^{13}$ Dengan demikian, karakter manifestasi cara pola berfikir dan ketika melakukan sesuatu yang sudah diketahui pada diri peserta didik. Ada tiga peristiwa karakter tentang perilaku manusia terdiri atas pengetahuan moral, perilaku manusia berdasarkan pada pengetahuan moral, dan perasaan manusia juga berdasarkan pengetahuan moral.

\footnotetext{
11 Akmal Mundiri et al., "Indigeneity and the Plight of Managing Behaviour; A Collaborative Instructional Model Based on Digital Classroom," Turkish Online Journal of Qualitative Inquiry (TOJQI) 12, no. 4 (2021): 1655-60.

12 Fathor Rozi and Innani Kholidatul Jannah, "Revitalisasi Pemberdayaan Budaya Karakter Nuansa Religiustik Dalam Membentuk Perilaku Pekerti Santri,” Muróbbî: Jurnal Ilmu Pendidikan 5, no. 1 (2021): 17-34.

${ }^{13}$ Fathor Rozi et al., "Learning Management; Identifying Learning Styles of Language Learners in Madrasah," Proceedings of the International Conference on Industrial Engineering and Operations Management 5, no. August (2020): 3783-90.
} 
Kemandirian adalah keadaan dapat berdiri sendiri tanpa bergantung kepada orang lain. Kemandirian merupakan salah satu tugas kemajuan yang bersifat dasar pada tahun-tahun perkembangan masa remaja yang fungsi sebagai bekal untuk menjadi orang dewasa kedepannya. Adanya belajar mandiri seorang siswa akan menentukan tujuan belajarnya, menyusun konsep selama proses pembelajarannya, mengarahkan pembelajarannya, melaksanakan pembelajaran dengan sumber yang jelas dan dipilih, dan melaksanakan kegiatan pembelajaran agar tercapainya tujuan belajarnya. Character education of a teacher seeks consciously and earnestly to teach values to his students. ${ }^{14}$

Pendidikan karakter mempunyai tujuan agar terbentuknya bangsa yang tangguh, bermoral, bertoleran, berakhlak mulia, berkembang dan penuh semangat, bergotong royong, berjiwa cinta pada tanah air, meninjau ilmu pengetahuan dan teknologi yang semuanya yang dijiwai oleh iman dan takwa kepada Tuhan Yang Maha Esa berdasarkan Pancasila. ${ }^{15}$ Mandiri adalah suatu sikap yang tidak mudah bergantung kepada orang lain untuk mencapai suatu tujuannya. Independent means trying to fulfill one's own needs, and it is not easy to depend on others. ${ }^{16}$ Jadi yang dimaksud pendidikan karakter mandiri adalah pembelajaran yang baik dan bersifat dasar atau pokok untuk membentuk suatu kepribadian seseorang dengan melalui pendidikan budi pekerti yang menghasilkan dan terlihat menjadi seseorang yang baik dan bertanggung jawab serta tidak melibatkan orang lain dalam menyelesaikan tugas-tugasnya. Dengan demikian, indikator dari pendidikan karakter mandiri meliputi; a) dapat menyelesaikan tugas dan tanggung jawab masing-masing, b) mempu mengatur kepribadian dirinya sendiri, c) sanggup mengatasi masalah individu, d) percaya dengan hasil kemampuan diri sendiri.

\section{Kecerdasan Moral}

Kecerdasan moral dideskripsikan tentang kesanggupan dalam memahami sesuatu yang baik dan tidak baik, yang artinya dapat mempunyai etika yang kuat ketika akan bertindak atas dasar keyakinan

\footnotetext{
14 Abd Hamid Wahid et al., "Effectiveness of Android-Based Mathematics Learning Media Application on Student Learning Achievement," in Journal of Physics: Conference Series (IOP Publishing, 2020), 1-7, https://doi.org/10.1088/17426596/1594/1/012047.

${ }^{15}$ Muhammad Mushfi El Iq Bali and Nurul Fadilah, "Internalisasi Karakter Religius Di Sekolah Menengah Pertama Nurul Jadid," Jurnal MUDARRISUNA: Media Kajian Pendidikan Agama Islam 9, no. 1 (2019): 1-25, https://doi.org/10.22373/jm.v9i1.4125.

16 Muhammad Mushfi El Iq Bali et al., "Utilization of Zoom Cloud in M3D (Maze 3D) Game-Based Learning to Develop Early Childhood Social-Emotional Skills," IOP Conference Series: Materials Science and Engineering 1125, no. 1 (2021): 012061, https://doi.org/10.1088/1757-899x/1125/1/012061.
} 
diri sendiri dan bersikap benar serta terhormat. Someone who is aware of moral values and will take action according to applicable values and norms without any coercion from others. ${ }^{17}$ Kecerdasan moral menjadi kecerdasan yang sangat penting tentang perihal karakter-karakter utama, dapat memahami penderitaan orang lain dan tidak melakukan tindakan kejahatan, bisa menerima dan menghargai setiap pendapat orang lain, mampu memberi pendapat atau nilai dari berbagai pihak, sanggup mengendalikan dorongan dan penunda pemuasan, mampu memahami perasaan dan pikiran orang lain, bias mengerti dengan pilihan yang tidak berhubungan dengan etika, dan mempunyai rasa kasih sayang dan rasa hormat kepada orang lain. Ini adalah sifat utama agar terbentuknya anak menjadi seorang yang baik hati.

Adanya manfaat kecerdasan moral yaitu dapat mempunyai karakter yang baik, mengajarkan siswa bagaimana cara bertindak yang baik agar menjadi siswa yang mengetahui tentang kecerdasan moral, dan memberi stimulus agar bangkitnya semangat sikap yang baik dan bisa membuat siswa menjadi sopan, mempunyai rasa peduli, dan hormat kepada siapapun meskipun beda usia. ${ }^{18}$ Kecerdasan moral juga membimbing siswa agar bersikap mengetahui keadaan dan cepat merespon kepada hal yang baik seperti mengatasi suatu permasalahan yang terjadi dan dapat menyelesaikan masalah dan mengambil keputusan yang sebagaimana mestinya. Seorang siswa yang memiliki kecerdasan moral akan mengetahui tentang persoalan yang berhubungan kepada kebenaran kehidupan dari yang berbeda. Dengan hal ini bahwa kecerdasan moral menjadikan seorang siswa mempunyai kemampuan dalam menyelesaikan suatu masalah dari berbagai kehidupan demi berperilaku dan bertindak yang baik kepada orang lain.

\section{Pembelajaran Daring}

Kerangka berfikir sistem pendidikan yang awalnya berbasis tradisional dengan cara tatap muka, kini beralih kepada sistem pendidikan tidak dibatasi oleh ruang dan waktu dengan menggunakan dunia teknologi informasi khususnya dunia Cyber (maya). Pembelajaran tatap muka terjadi adanya hubungan tentang pembelajaran yang dilakukan seorang pendidik dan peserta didik yang meluangkan waktu dan tempat yang sama. Pembelajaran tatap muka merupakan

\footnotetext{
${ }^{17}$ Moch Tohet et al., "Characters Education Based Audiovisual for Children in the Coastal Area," Turkish Online Journal of Qualitative Inquiry (TOJQI) 12, no. 4 (2021): 1639_ 44.

18 Muhammad Mushfi El Iq Bali and Susilowati, "Transinternalisasi Nilai-Nilai Kepesantrenan Melalui Konstruksi Budaya Religius Di Sekolah," Jurnal Pendidikan Agama Islam 16, no. 1 (2019): 1-12, https://doi.org/10.14421/jpai.2019.161-01.
} 
pembalajaran yang tradisional. Bersamaan dengan adanya perkembangan teknologi informasi dan perkembangan pembelajaran juga sering mengalami perubahan. The development of learning began with a face-to-face method and increasingly stretched with the existence of online learning. Online learning can also be called electronic learning or called E-learning. ${ }^{19}$

E-learning sudah mewakili pembelajaran dengan proses pembelajaran tatap muka secara jarak jauh. E-learning is a continuous adjustment of knowledge and skills to adolescent students. ${ }^{20}$ Penyesuaian tersebut sesuatu dorongan atau rangsangan oleh pembelajaran secara waktu yang sama ataupun tidak serentak menggunakan teknologi internet. E-learning sangat membantu pada proses pembelajaran tatap muka yaitu salah satunya tentang hal penyebaran atau pembagian materi pelajaran, proyek dari pendidikan kepeserta didik dan pekerjaan rumah. ${ }^{21}$ Secara keseluruhan dapat dikatakan bahwa E-learning dapat membantu pada proses pembelajaran yang tidak bisa dilakukan secara tatap muka. Untuk mencapai suatu tujuan pembelajaran, pembelajaran tatap muka melalui pembelajaran online akan lebih memaksimalkan usaha pendidik sebagai pengajar.

Ciri-ciri khas dari E-learning yaitu tidak perlu memakan waktu dan tempat (ruang). Selama pembelajaran berlangsung dapat dilaksanakan kapan dan dimana saja. Dengan adanya teknologi informasi yang canggih, E-learning dapat mempersiapkan tentang bahan ajar dan menyimpan suatu arahan pembelajaran yang dapat di akses dimanapun dan kapanpun. Adanya pelaksanaan pembelajaran E-learning tidak membutuhkan ruangan atau tempat yang besar dan luas selama pelaksanaan pembelajaran berlangsung. Dengan seperti ini teknologi dapat memperpendek jarak antara peserta didik dan pendidik.

E-learning juga memanfaatkan teknologi informasi dan komunikasi sebagai alat, adanya maksud ingin meningkatkan efisiensi, keefektifan, akuntabilitas, transparansi, dan keadaan kenyataan belajar, dengan hal adanya layanan pembelajaran yang menarik, aktif, dan menyenangkan. Hasil akhir yang ingin diharapkan adanya peningkatan prestasi dan kemampuan akademik para peserta didik dan dapat pengurangan biaya,

\footnotetext{
19 Bali et al., "Innovative Learning Media Based on E-Learning in the New Normal Era."

${ }^{20}$ Chusnul Muali et al., "Free Online Learning Based on Rich Internet Applications; The Experimentation of Critical Thinking about Student Learning Style," in Journal of Physics: Conference Series, vol. 1114 (Institute of Physics Publishing, 2018), 1-6, https://doi.org/10.1088/1742-6596/1114/1/012024.

21 Muhammad Mushfi El Iq Bali, "Implementasi Media Pembelajaran Berbasis Teknologi Informasi Dan Komunikasi Dalam Distance Learning," Tarbiyatuna: Kajian Pendidikan Islam 3, no. 1 (2019): 28-38.
} 
tenaga dan waktu. The E-learning learning process for the characters, namely; (1) Can take advantage of electronic technology services, where teachers and students, all students and teachers can communicate relatively quickly and without being limited by the pandemic protocol. (2) Can take advantage of the learning schedule, curriculum, and the results of learning progress, and those related to education administration can be viewed at any time on the cellphone. ${ }^{22}$

To get interesting and desirable E-learning learning outcomes in designing Elearning, three conditions must be met: simple, personal, and fast. ${ }^{23}$ Sistem yang sederhana dapat mempermudah para peserta didik dalam kegunaan teknologi dan menu yang ada. Dan kemudahan panel yang sudah tersedia, akan berkurang dalam pengenalan E-learning itu sendiri. Sehingga waktu belajar para peserta didik lebih menghasilkan dari proses belajar bukan proses belajar yang menggunakan sistem E-learning.

\section{Metodologi Penelitian}

Jenis penelitian ini menggunakan pendekatan penelitian kualitatif deskriptif. Qualitative research is used in conditions that are discovery and natural. ${ }^{24}$ Dalam penelitian kualitatif, penelitian termasuk instrument kunci. Descriptive research is research conducted because it describes a variable, either one or more variables without any difference, or connects one variable to another. ${ }^{25}$ Penelitian ini menghimpun data yang berupa data kalimat atau menguraikan data dari subjek penelitian yang dilakukan secara wawancara. Subjek tersebut terdiri dari guru Pendidikan Agama Islam di MAN 2 Probolinggo. Instrumen peneliti terdiri dari peneliti sebagai instruemen utama dengan instrumen wawancara. Data dari penelitian ini merupakan hasil wawancara, yang merupakan hasil jawaban dari subjek yang mendeskripsikan dari urgensi pengembangan karakter mandiri dalam mengembangkan kecerdasan moral melalui pembelajaran daring.

\section{Hasil dan Pembahasan}

Peserta didik dari MAN 2 Probolinggo yang berawal memiliki sikap sopan santun dan teguh pendirian tetapi dari sebagian murid masih

\footnotetext{
22 Bali et al., "Innovative Learning Media Based on E-Learning in the New Normal Era."

${ }^{23}$ Dewi Oktavia et al., "Exploration of Fine Motor Skills through the Application of Paint," in WESTECH (European Alliance for Innovation n.o., 2019), 1-6, https://doi.org/10.4108/eai.8-12-2018.2284038.

24 Jan van den Akker et al., "Educational Design Research: An Introduction," Educational Design Research, 2013, 204, https://doi.org/10.1007/978-1-4614-3185-5_11.

${ }^{25}$ John W Creswell, Educational Research: Planning, Conducting, and Evaluating Quantitative and Qualitative Research, PEARSON, 4th ed. (Boston: Pearson Education, Inc., 2012), https://doi.org/10.1017/CBO9781107415324.004.
} 
saja perlunya suatu bimbingan, supaya mempunyai kecerdasan moral. Dari 129 siswa di MAN 2 Probolinggo ada 16 siswa yang masih belum dapat memperaktikkan dengan betul dan baik kecerdasan moral. Ada 4 siswa MAN 2 Probolinggo yang keluar kelas di jam mata pelajaran tanpa sepengetahuan guru dan akhirnya mekeka mendapatkan hukuman (punishment) seperti pemanggilan orang tua, rambut di gundul dll. Dimasa saat ini banyaknya suatu perubahan yang sangat besar di berbagai daerah dengan melewati perihal teknologi, yang dapat mengurangi perbatasan antara dunia fisik, digital, dan sifat manusia. Penting adanya perubahan suatu moral yang mengalami suatu ancaman bisa menjadikan goyahnya moral seorang siswa. Dapat kurangnya kesadaran pada seorang siswa yaitu suatu hal-hal penting memiliki perilaku yang baik, bercakap dengan halus, dan berlaku sopan pada diri peserta didik yang dapat menjadikan penyebab kurangnya kecerdasan moral pada siswa MAN 2 Probolinggo.

Adanya kegiatan sekolah yaitu pembelajaran dikelas maupun diluar kelas mesti didasari rasa semangat berproses, dan juga semangat adanya perubahan yang lebih baik. Ada sebuah hadits yang menjelaskan bahwa "hari ini harus lebih baik dari kemarin" dan "sebaik-baiknya manusia adalah yang paling bermanfaat bagi sesamanya" menjadi suatu landasan bahwa melakukan pembelajaran dapat adanya dasar suatu perubahan. Bagian dari semangatnya perubahan, yaitu berproses pembalajaran dalam menyatakan suatu metode belajar pada peserta didik dan menjadi pengajar pada pendidik. Adanya prinsip pembentukan karakter mandiri disajikan pada tabel berikut.

Tabel 1. Prinsip Pembentukan Karakter Mandiri

\begin{tabular}{ll}
\hline \multicolumn{1}{c}{ Indikator } & \multicolumn{1}{c}{ Deskripsi } \\
\hline Berdasarkan pada & Dalam rangka pembentukan pembelajaran \\
realita & karakter mandiri yang berawal dari realita \\
& yang nyata dapat mengarahkan para peserta \\
& didik. Realita ini sangat penting dan \\
& berpengaruh atas apa yang dilakukan atau \\
& dipahami pada peserta didik dan betul-betul \\
& nyata apa yang dialami. Dengan begitu, \\
& peserta didik akan terbentuk kuat dan \\
& tangguh, dan juga tidak mudah putus asa \\
& disertai kemauan keras tentang suatu \\
& persoalan yang akan dihadapi siswa \\
& dikehidupan nyata. \\
\hline Belajar untuk berkarya & Pembelajaran bukan hanya tentang teori dan \\
& menghadapi teks. Belajar adalah usaha agar \\
& terpenuhinya kebutuhan dan keinginan, dan \\
\hline
\end{tabular}




\begin{tabular}{ll}
\hline \multicolumn{1}{c}{ Indikator } & \multicolumn{1}{c}{ Deskripsi } \\
\hline & juga dapat mengatasi suatu permasalahan \\
& kehidupan. "Berprestasi" ketika anak telah \\
& mendapatkan suatu jawaban tentang \\
& persoalan dan pertanyaan yang realita \\
& dikehidupannya yaitu memperlihatkan suatu \\
& tindakan dan karya nyata. \\
\hline Membangun & Adanya terbangun suatu kemandirian dan \\
kemandirian dan & kebersamaan dengan mengawali cara \\
kebersamaan & berfikirnya siswa yang mandiri, untuk \\
& membangun rasa kebersamaan yaitu \\
& bermodal sikap kemandirian. Gurunya, \\
& terbentuknya kepribadian siswa yang baik \\
& seorang guru membangkitkan kerja sama \\
& dan rasa kebersamaan dapat saling \\
& melengkapi, dapat mewujudkan siswa yang \\
kuat dan tangguh. & \\
\hline Tidak berhenti berfikir & Seorang guru harus mendorong \\
dan berkarya & $\begin{array}{l}\text { perkembangan sikap memberikan rasa } \\
\text { semangat dan mencari pengetahuan yang }\end{array}$ \\
& $\begin{array}{l}\text { lebih banyak, menciptakan inovasi baru, } \\
\text { berkarya, dan mencoba hal-hal yang baru }\end{array}$ \\
& untuk membangun rasa semangat. \\
\hline
\end{tabular}

Peran guru Pendidikan Agama Islam dalam membangun kecerdasan moral pada siswa MAN 2 Probolinggo: (1) Mengerti dengan benar tentang materi, susunan pembelajaran, konsep dan pola pikir keilmuan yang membantu mata pelajaran Pendidikan Agama Islam. (2) Menunjukkan bahwa pentingnya mata pelajaran Pendidikan Agama Islam agar meningkatnya moral siswa. Guru Pendidikan Agama Islam memiliki tugas tersendiri dan harus memiliki kemampuan menguasai dalam bidang pengetahuan nilai, dan sikap supaya bisa memahami seperti apa kondisi siswa. Guru sebagai contoh atau sesuatu yang patut ditiru bagi semua siswa baik di luar kelas maupun di dalam kelas. Guru bukan hanya seorang pengajar atau pendidik, melainkan juga sebagai pendidik dalam mengembangkan nilai-nilai moral pada diri siswa. Upaya guru Pendidikan Agama Islam terus menerus berusaha dalam menerapkan sikap serta nilai yang terkandung dalam agama sehingga dapat mempraktikkan dan juga diikuti oleh para siswa. Guru Pendidikan Agama Islam ketika saat proses kegiatan belajar mengajar selalu mengulas kembali dengan yang berkaitan dengan nilai, moral dan sikap dengan peristiwa yang sederhana, 
mengingatkan kembali untuk memiliki sifat toleransi, adil, empati, dan meningkatkan rasa hormat terhadap guru atau kepada orang yang lebih tua dan peristiwa yang menyangkut dengan moral. Dengan begitu moral adalah suatu pelajaran kesusilaan yang menyangkut dengan tata cara atau aturan yang mengatur baik buruknya suatu hal. Tata cara yang membuat perilaku peserta didik ini dapat berbentuk tertulis maupun lisan. Peraturan ini dapat adanya dari adat istiadat, bersumber dari agama atau hukum negara.

\section{Penutup}

Peran seorang guru sangatlah penting, guru wajib mampu menjadi fasilitator dan menjelaskan kelemahan model-model dan segala keunggulan pembelajaran yang akan diterapakan sehingga benar-benar menjadikan sesuatu pembelajaran yang baru dari hasil pengaruh terhadap proses pembelajaran. Pendidikan karakter yang membentuk nilai pendidikan, pendidikan moral, pendidikan watak mempunyai tujuan agar luasnya pengetahuan dan kecakapan pada peserta didik sebab menentukan hal yang baik dan yang buruk. Beberapa masalah tentang kecerdasan moral dengan turunnya nilai akhlak dan moral telah menjadi salah satu yang masih menimbulkan masalah yang melanda dunia pendidikan dan masyarakat. Manfaat kecerdasan moral yaitu dapat mempunyai karakter yang baik, mengajarkan siswa bagaimana cara bertindak yang baik agar menjadi siswa yang mengetahui tentang kecerdasan moral, dan memberi stimulus agar bangkitnya rasa semangat sikap yang baik dan bisa membuat siswa menjadi sopan, mempunyai rasa peduli, dan hormat kepada siapapun meskipun beda usia. Upaya guru dalam proses kegiatan belajar mengajar selalu mengulas kembali dengan yang berkaitan dengan nilai, moral dan sikap dengan peristiwa yang sederhana, mengingatkan kembali untuk memiliki sifat toleransi, adil, empati, dan meningkatkan rasa hormat terhadap guru atau kepada orang yang lebih tua dan peristiwa yang menyangkut dengan moral.

\section{Daftar Pustaka}

Akker, Jan van den, Brenda Bannan, Anthony Kelly, Tjeerd Plomp, and Nienke Nieveen. "Educational Design Research: An Introduction." Educational Design Research, 2013, 204. https://doi.org/10.1007/978-1-4614-3185-5_11.

Bali, Muhammad Mushfi El Iq. "Implementasi Media Pembelajaran Berbasis Teknologi Informasi Dan Komunikasi Dalam Distance Learning." Tarbiyatuna: Kajian Pendidikan Islam 3, no. 1 (2019): 2838. 
"Penerapan Model Pembelajaran Two Stay Two Stray Dalam Meningkatkan Keaktifan Belajar Matematika." Murobbi: Jurnal Ilmu Pendidikan 4, no. 1 (2020): 29-42.

Bali, Muhammad Mushfi El Iq, Hasan Baharun, Ahmad Madanibillah, Chusnul Muali, Lukman, Nanang Khoirul Anam, Zamroni, and Abdul Talib Bon. "Innovative Learning Media Based on ELearning in the New Normal Era." In 11th Annual International Conference on Industrial Engineering and Operations Management Singapore, 1-7, 2021.

Bali, Muhammad Mushfi El Iq, and Nurul Fadilah. "Internalisasi Karakter Religius Di Sekolah Menengah Pertama Nurul Jadid." Jurnal MUDARRISUNA: Media Kajian Pendidikan Agama Islam 9, no. 1 (2019): 1-25. https://doi.org/10.22373/jm.v9i1.4125.

Bali, Muhammad Mushfi El Iq, and Musrifah. "The Problems of Application of Online Learning in the Affective and Psychomotor Domains During the Covid-19 Pandemic." Jurnal Pendidikan Agama Islam 17, no. 2 (2020): 137-54. https://doi.org/https://doi.org/10.14421/jpai.2020.172-03.

Bali, Muhammad Mushfi El Iq, Najiburrahman, Alvan Fathony, Salma, Eva Maghfirah, and Lia Ayu Farida. "Utilization of Zoom Cloud in M3D (Maze 3D) Game-Based Learning to Develop Early Childhood Social-Emotional Skills." IOP Conference Series: Materials Science and Engineering 1125, no. 1 (2021): 012061. https://doi.org/10.1088/1757-899x/1125/1/012061.

Bali, Muhammad Mushfi El Iq, and Lailatul Rohmah. "Implementasi Pendekatan Eklektik Berbasis Sharing Zone." Murobbi: Jurnal Ilmu Pendidikan 6, no. 2 (2018): $152-67$. http://jurnal.iaibafa.ac.id/index.php/murobbi/article/view/143.

Bali, Muhammad Mushfi El Iq, and Devi Ruzifah. "Mitigation of Student Deviant Behaviour through Al-Ghazali's Perspective Spiritual Values in the Disruptive Era." Jurnal Pendidikan Progresif 11, no. 1 (2021): 63-76. https://doi.org/10.23960/jpp.v11.i1.20210.

Bali, Muhammad Mushfi El Iq, and Susilowati. "Transinternalisasi NilaiNilai Kepesantrenan Melalui Konstruksi Budaya Religius Di Sekolah." Jurnal Pendidikan Agama Islam 16, no. 1 (2019): 1-12. https://doi.org/10.14421/jpai.2019.161-01.

Creswell, John W. Educational Research: Planning, Conducting, and Evaluating Quantitative and Qualitative Research. PEARSON. 4th ed. Boston: Pearson Education, Inc., 2012. https://doi.org/10.1017/CBO9781107415324.004.

Dakir, Muhammad Mushfi El Iq Bali, Zulfajri, Chusnul Muali, Hasan 
Baharun, Dani Ferdianto, and Muhammad Salman Al-Farisi. "Design Seamless Learning Environment in Higher Education with Mobile Device." In WEAST 2020, 1-6. IOP Publishing, 2021. https://doi.org/10.1088/1742-6596/1899/1/012175.

Muali, Chusnul, Syaiful Islam, Muhammad Mushfi El Iq Bali, H. Hefniy, Hasan Baharun, Akmal Mundiri, Moh Jasri, and Ahmad Fauzi. "Free Online Learning Based on Rich Internet Applications; The Experimentation of Critical Thinking about Student Learning Style." In Journal of Physics: Conference Series, 1114:1-6. Institute of Physics Publishing, 2018. https://doi.org/10.1088/17426596/1114/1/012024.

Mundiri, Akmal, Muhammad Mushfi El Iq Bali, Hasan Baharun, Moh Holidi, Frisky Ervansyah, Athaur Rahman Abbas, Dahlan Abdullah, and Cut Ita Erliana. "Indigeneity and the Plight of Managing Behaviour; A Collaborative Instructional Model Based on Digital Classroom." Turkish Online Journal of Qualitative Inquiry (TOJQI) 12, no. 4 (2021): 1655-60.

Oktavia, Dewi, Muhammad Mushfi El Iq Bali, Handono Rahman, Umar Umar, Agus Syakroni, and Faizatul Widat. "Exploration of Fine Motor Skills through the Application of Paint." In WESTECH, 1-6. European Alliance for Innovation n.o., 2019. https://doi.org/10.4108/eai.8-12-2018.2284038.

Rozi, Fathor. "Variations in Learning Methods; Upaya Dalam Mencetak Pakar Fiqh Melalui Pengembangan Pembelajaran Kitab Kuning Di Ma'had Aly." Tafaqqub: Jurnal Penelitian Dan Kajian Keislaman 9, no. 1 (2021): 81-98.

Rozi, Fathor, Muhammad Mushfi El Iq Bali, Sulton Firdaus, Muallim Wijaya, Rahmatul Aziz Al Mursyidi, Moh Wasil Haqiki, and Zainal Abidin. "Learning Management; Identifying Learning Styles of Language Learners in Madrasah." Proceedings of the International Conference on Industrial Engineering and Operations Management 5, no. August (2020): 3783-90.

Rozi, Fathor, and Innani Kholidatul Jannah. "Revitalisasi Pemberdayaan Budaya Karakter Nuansa Religiustik Dalam Membentuk Perilaku Pekerti Santri." Muróbbî: Jurnal Ilmu Pendidikan 5, no. 1 (2021): $17-$ 34.

Santika, I Wayan Eka. "Pendidikan Karakter Pada Pembelajaran Daring." Indonesian V alues and Character Education Journal 3, no. 1 (2020): 8-19.

Tohet, Moch, Muhammad Mushfi El Iq Bali, Dina Putri Juni Astuti, Alwiya Ulfa, Siti Maisaroh, Hariroh Ashidqiah, Dahlan Abdullah, Kamaruddin Hasan, Teuku Muhammad Ridwan, and Cut Ita 
Erliana. "Characters Education Based Audiovisual for Children in the Coastal Area." Turkish Online Journal of Qualitative Inquiry (TOJQI) 12, no. 4 (2021): 1639-44.

Wahid, Abd Hamid, Najiburrahman, Kholilur Rahman, Faiz, Khodijatul Qodriyah, Hambali, Muhammad Mushfi El Iq Bali, Hasan Baharun, and Chusnul Muali. "Effectiveness of Android-Based Mathematics Learning Media Application on Student Learning Achievement." In Journal of Physics: Conference Series, 1-7. IOP Publishing, 2020. https://doi.org/10.1088/17426596/1594/1/012047.

Wahid, Abdul Hamid, Muhammad Mushfi El Iq Bali, and Sofiatul Maimuna. "Problematika Pembelajaran Fiqih Terhadap Minat Belajar Siswa Dalam Pembelajaran Jarak Jauh.” Edureligia: Jurnal Pendidikan Agama Islam 05, no. 01 (2021): 1-17.

Zamroni, Hasan Baharun, Hefniy, Muhammad Mushfi El Iq Bali, and Kusmiyatun Hasanah. "Leader Member Exchange Dalam Membangun Komunikasi Efektif Di Pondok Pesantren.” ElBubuth: Borneo Journal of Islamic Studies 3, no. 1 (2020): 77-89. 